\title{
INVENTARISASI JAMUR PATOGEN TULAR-BENIH PADA LIMA VARIETAS PADI
}

\author{
Sifa Sobianti ${ }^{1)}$, Loekas Soesanto $^{\left.{ }^{*}\right)}$, Suciati Hadi $^{2)}$ \\ ${ }^{1)}$ Program Studi Agroteknologi, Fakultas Pertanian Universitas Jenderal Soedirman \\ J1. Dr. Soeparno 73, Purwokerto, 53123 \\ ${ }^{2}$ Peneliti Balai Karantina Pertanian Kelas I Semarang \\ ${ }^{1 *}$ Email korespondensi: lukassusanto26@gmail.com
}

\begin{abstract}
This research aimed to know (1) various species of seed-borne pathogenic fungi in five paddy varieties, and (2) germination percentage of five paddy varieties. The research was conducted at the Laboratory of Class I Agricultural Quarantine Institute Semarang, from March until May 2019. This research used completely Randomized Design with five treatments and five replicates. The treatments were Inpago Unsoed 1, Inpago Unsoed Parimas, IR64, Ciherang, and Situ Bagendit varieties. Isolation and identification of seed-borne pathogenic fungi was carried out on blotter test and PDA observed under stereo and compound microscope, then compared to literatures. Variables observed were pathogenic colonies morphology, fungal pathogen morphology, and germination percentage. Result of the research showed that (1) in all varieties of paddy seeds there are seed-borne pathogenic fungi, but not all fungi are found in each variety. Various type of seed-borne pathogenic fungi found were Alternaria padwickii Ganguly, Aspergillus flavus Link, Aspergillus niger van Tieghem, Curvularia lunata (Wakker) Boedjin, Curvularia pallescens Boedjin, Drechslera oryzae Breda de Haan, Fusarium semitectum Berk. \& Rav. [W\&R, G,B,J], Rhizoctonia solani J. G. Kuhn, Rhizopus oryzae Went \& Prins. Geerl., dan Tilletia barclayana Bref., and (2) every paddy variety differed seed germination percentage. The germination percentage was found from IR64 to Ciherang, Inpago Unsoed 1, Inpago Unsoed Parimas, and Situ Bagendit as 85.75, 81.75, 80.25, 76.5, and 70\%, respectively.
\end{abstract}

Keywords: inventory, seed-borne pathogenic fungi, paddy varieties.

\begin{abstract}
Abstrak. Penelitian ini bertujuan untuk mengetahui (1) beragam spesies jamur patogen tular-benih pada lima varietas padi, dan (2) persentase daya kecambah lima varietas padi. Penelitian dilaksanakan di Laboratorium Karantina Pertanian Kelas I Semarang, dari bulan Maret sampai dengan Mei 2019. Penelitian ini menggunakan Rancangan Acak Lengkap dengan 5 perlakuan dan 5 ulangan, perlakuan terdiri atas Varietas Inpago Unsoed 1, Inpago Unsoed Parimas, IR64, Ciherang, dan Situ Bagendit. Isolasi dan identifikasi jamur patogen tular-benih dilakukan pada blotter test dan medium PDA, dengan pengamatan di bawah mikroskop stereo dan kompon, kemudian dibandingkan dengan pustaka. Variabel yang diamati yaitu morfologi koloni patogen, morfologi patogen, dan daya kecambah. Hasil penelitian menunjukkan bahwa (1) pada semua varietas benih padi terdapat jamur patogen tular-benih, tetapi tidak semua jamur tersebut dijumpai pada setiap varietas. Jenis jamur patogen tular-benih yang dijumpai, yaitu Alternaria padwickii Ganguly, Aspergillus flavus Link, Aspergillus niger van Tieghem, Curvularia lunata (Wakker) Boedjin, Curvularia pallescens Boedjin, Drechslera oryzae Breda de Haan, Fusarium semitectum Berk. \& Rav. [W\&R, G,B,J], Rhizoctonia solani J. G. Kuhn, Rhizopus oryzae Went \& Prins. Geerl., dan Tilletia barclayana Bref., dan (2) uji daya kecambah menunjukkan bahwa masingmasing varietas benih padi memilki persentase daya kecambah benih yang berbeda. Daya kecambah benih berturut-turut pada varietas IR64, Ciherang, Inpago Unsoed 1, Inpago Unsoed Parimas, dan Situ Bagendit sebesar 85,75, 81,75, 80,25, 76,5, dan 70\%.
\end{abstract}

Kata kunci: inventarisasi, jamur patogen tular-benih, varietas padi.

\section{PENDAHULUAN}

Tanaman padi (Oryza sativa L.) merupakan tanaman pangan utama di Indonesia, karena sebagian

besar penduduk Indonesia
menjadikan beras sebagai bahan
makanan pokok. Upaya untuk
meningkatkan produktivitas padi
telah banyak dilakukan, tetapi


terdapat kendala yang dapat menurunkan produktivitas padi. Salah satu kendala adalah kurang tersedianya benih padi bermutu (Saylendra, 2010).

Benih bermutu merupakan benih yang memiliki mutu genetika, fisiologi, dan status kesehatan yang baik. Salah satu faktor yang menentukan status kesehatan benih yaitu bebas dari patogen tular-benih baik jamur, bakteri, maupun virus patogen. Benih yang terinfeksi patogen akan tumbuh menjadi kecambah dan tanaman yang tidak sehat, sehingga tidak mampu berproduksi optimum (Hausufa \& Rusae, 2018).

Upaya untuk mendapatkan benih bebas dari kontaminasi jamur patogen perlu dilakukan. Salah satu upaya yang dapat dilakukan adalah dengan pengujian kesehatan benih. Uji kesehatan benih dilakukan dengan teknik isolasi, dilanjut dengan identifikasi. Deteksi dan identifikasi merupakan kegiatan penting dalam pengelolaan penyakit tanaman, karena dengan diketahuinya status kesehatan benih dan identitas patogen terbawa benih akan dapat ditentukan strategi pengendalian lebih awal dan tepat waktu untuk mencegah terjadinya penyebaran, epidemi, dan kehilangan hasil (Cram \& Fraedrich, 2010).

Informasi tentang identifikasi jamur tular-benih, khususnya benih padi masih perlu dikembangkan untuk meningkatkan kualitas benih di Indonesia. Berdasarkan uraian tersebut, maka perlu dilakukan penelitian untuk inventarisasi jamur patogen tular-benih dan untuk mengetahui daya kecambah benih padi pada beberapa varietas.
Penelitian ini bertujuan untuk mengetahui beragam jenis jamur patogen tular-benih pada lima varietas padi, dan persentase daya kecambah benih pada lima varietas padi.

\section{METODE PENELITIAN}

Penelitian ini dilaksanakan di Laboratoium Balai Karantina Pertanian Kelas I Semarang, yang dilakukan pada bulan Maret sampai dengan Mei 2019.

\section{Penyiapan Benih Padi}

Benih padi yang terdiri atas 5 varietas padi (Inpago Unsoed 1, Inpago Unsoed Parimas, Ciherang, IR 64, dan Situ Bagendit) diambil masing-masing sebanyak 400 benih secara acak, kemudian diinkubasi dengan metode Blotter test. Sebanyak 40 benih pada masingmasing varietas diambil untuk diinkubasi pada medium PDA.

\section{Isolasi pada Kertas Saring}

Isolasi pada kertas saring ditujukan untuk mendapatkan jamur yang menempel di bagian luar benih. Benih padi diambil sebanyak 400 benih dari setiap varietas. Benih disterilkan permukaan dengan direndam NaOCL $1 \%$ selama 3 menit, kemudian dibilas dengan aquades dan dikering-anginkan. Sebanyak 3 lembar kertas saring steril dilembapkan dengan air steril, kemudian dimasukkan ke dalam cawan Petri. Benih diletakkan pada masing-masing cawan Petri di Laminar Air Flow (LAF). Cawan Petri yang berisi benih padi kemudian diinkubasi selama 7 hari pada suhu ruang. Setelah 7 hari benih yang diinkubasi tersebut diamati di bawah mikroskop stereo dan 
mikroskop kompon (Pratiwi et al., 2016).

\section{Isolasi dan Pemurnian Jamur}

Benih padi diambil sebanyak 40 benih setiap varietas. Benih padi disterilkan permukaannya dengan cara direndam $\mathrm{NaOCl} 1 \%$ selama 3 menit dan dibilas dengan larutan aquades steril 1 menit. Benih ditiriskan pada kertas tisu, setelah kering benih diletakkan ke dalam cawan Petri berisi medium PDA yang diperkaya dengan antibiotika. Peletakan benih dilakukan secara aseptis, kemudian cawan Petri ditutup dengan seal dan diinkubasi selama 7 hari pada suhu ruang hingga jamur tumbuh (Sucipto et al., 2015). Koloni jamur yang tumbuh selanjutnya direisolasi terpisah atau dimurnikan pada medium PDA baru, diinkubasi selama 7 hari pada suhu ruang, sehingga diperoleh isolat murni, yang siap digunakan untuk identifikasi.

\section{Variabel yang Diamati}

Pengamatan dilakukan untuk mengetahui beberapa variabel yaitu morfologi jamur secara makroskopis dan mikroskopis, dan menghitung persentase perkecambahan setiap varietas padi.

1. Morfologi koloni patogen

(Makroskopis)

Pengamatan makroskopis dilakukan secara visual dengan menggunakan mata secara langsung dan mikroskop stereo untuk melihat pertumbuhan jamur meliputi warna dan bentuk permukaan koloni (Ningsih et al., 2012).

2. Morfologi jamur patogen
(Mikroskopis)
Pengamatan mikroskopis dilakukan dengan diawali pembuatan preparat setiap jamur yang tumbuh pada padi. Biakan murni secara aseptis dengan jarum ose diambil dan diletakkan ke permukaan gelas preparat dan diamati dengan mikroskop (Ningsih et al., 2012). Pengamatan mikroskopis dilakukan dengan melihat bentuk fialid, bentuk miselium, bentuk makrop dan mikrokonidium, serta ukuran konidium (Ngittu et al., 2014).

3. Daya kecambah benih (\%)

Perhitungan persentase daya kecambah dilakukan pada benih yang berkecambah normal dengan menggunakan rumus (ISTA, 1996):

Daya

Kecambah=

$\frac{\sum \text { kecambah normal }}{\sum \text { benih yang dikecambahkan }} \times 100 \%$

\section{Analisis Data}

Analisis pada tahap identifikasi dilakukan secara deskriptif dengan mengamati ciri-ciri khas setiap isolat jamur hasil isolasi dari benih padi dan dibandingkan dengan pustaka Common Laboratory Seed Health Testing Methods for Detecting Fungi (Mathur \& Kongsdal, 2003), Dematiaceous Hyphomycetes (Ellis, 1997), A Pictorial Guide for the Identification of Mold Fungi on Sorghum Grain (Navi et al., 1999), dan pustaka lainnya. Data daya kecambah yang diperoleh dianalisis menggunakan uji $\mathrm{F}$ dan bila menunjukkan hasil yang berpengaruh nyata dilanjutkan dengan uji BNJ pada taraf kesalahan 5\%.

\section{HASIL DAN PEMBAHASAN}

\section{Jamur Patogen Tular-Benih Padi}

Hasil pengamatan dan identifikasi terhadap isolat jamur 
yang tumbuh pada metode blotter test dan medium agar di lima varietas benih padi menunjukkan beragam jenis jamur tular-benih (Tabel 1). Berdasarkan pembanding pustaka acuan, jamur tular-benih yang diidentifikasi adalah Alternaria padwickii Ganguly, Aspergillus flavus Link, Aspergillus niger van Tieghem, Curvularia lunata (Wakker) Boedjin, Curvularia pallescens Boedjin, Drechslera oryzae Breda de Haan, Fusarium semitectum Berk. \& Rav. [W\&R, G,B,J], Rhizoctonia solani J. G. Kuhn, Rhizopus oryzae Went \& Prins. Geerl., dan Tilletia barclayana Bref. Sebaran jamur tersebut di lima varietas benih padi dapat dilihat pada Tabel 1.

Tabel 1. Jamur-jamur tular-benih di lima varietas benih padi.

\begin{tabular}{|c|c|c|c|c|c|}
\hline \multirow{2}{*}{ Jamur } & \multicolumn{4}{|c|}{ Varietas } & 2011; Uma \& Wesely, 2013). \\
\hline & V1 & $\mathrm{V} 2$ & V3 & V4 & V5 \\
\hline $\begin{array}{l}\text { Alternaria } \\
\text { padwickii }\end{array}$ & + & + & + & + & $\begin{array}{l}\text { Karakteristik } \\
{ }^{+} \text {Tular-Benih }\end{array}$ \\
\hline Aspergillus flavus & + & - & - & - & _. Alternaria padwickii Ganguly \\
\hline$A$. & - & + & - & T & Jamur Alternaria padwicki \\
\hline Curvularia lı & - & + & & & _menyebabkan penyakit Stackbu \\
\hline C. pallesce & - & + & & & „pada tanaman padi (Mew \\
\hline Drechslera oryzae & - & - & + & - & +Gonzalez, 2002). Hasil pengamatan \\
\hline Fusarium & & & & & menunjukkan \\
\hline & + & + & + & + & 'koloni jamur tular-benih berw \\
\hline Rhizoctonia solani & + & + & - & 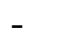 & „putih dengan permukaan berbe \\
\hline Rhizc & + & - & 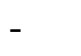 & + & rata, bagian tepi koloni rata \\
\hline Tillet & & + & & & _bertekstur lengket (Gambar \\
\hline $\begin{array}{l}\text { Keterangan: }+=\text { dijl } \\
\text { dijumpai. V1 = } \\
1, \mathrm{~V} 2=\text { Inpago } \\
\text { V3 = IR 64, V4 } \\
\text { V5 = Situbagend } \\
\text { Dari tabel ter } \\
\text { bahwa jamur tul } \\
\text { dominan dijumpai } \\
\text { badwickii. A niger. }\end{array}$ & $\mathrm{ns}$ & $\begin{array}{l}\text { Par } \\
\text { rang }\end{array}$ & $\begin{array}{l}\text { ui } \\
\text { ng } \\
\text { A. }\end{array}$ & & $\begin{array}{l}\text { Jamur ini mempunyai konidium } \\
\text { lurus, memiliki 3-5 septa, berbentuk } \\
\text { paruh panjang, dan tanwarna. } \\
\text { Konidiofor tanwarna dan panjang } 95- \\
170 \mu \mathrm{m} \text { (Gambar } 2 \mathrm{a} \text { ). Berdasarkan } \\
\text { ciri-ciri morfologi yang diamati, } \\
\text { jamur tersebut diduga } A \text {. padwickii, } \\
\text { yang sesuai dengan Gambar } 2 \mathrm{~b} \text {. } \\
\text { Menurut Mathur dan Kongsdal, }\end{array}$ \\
\hline
\end{tabular}

R. solani, dan Rhizopus oryzae di lima varietas padi. Hal ini diduga jamur tersebut merupakan kelompok jamur tular-benih yang banyak ditemukan di daerah penanaman padi baik sawah maupun lahan kering, dan dapat menimbulkan penyakit tanaman padi sejak di lapangan, juga dapat menginfeksi benih dalam penyimpanan. Infeksi Alternaria dan Fusarium dapat terjadi sejak tanaman padi di lapangan karena mikroba tersebut merupakan patogen penting pada tanaman padi (Desjardins et al., 2000; Quintana, et al., 2017). Aspergillus dan Rhizopus hampir selalu ditemukan pada benih karena jamur tersebut adalah parasit fakultatif yang lebih dikenal dengan nama jamur gudang, karena ditemukan pada benih di tempat penyimpanan (Ibeabuchi \& Olawuni, 2011; Uma \& Wesely, 2013). 
putih, pada benih yang terinfeksi terkadang dikelilingi oleh noda merah muda-ungu yang merupakan indikasi infeksi oleh A. padwickii (Gambar 1b). Menurut Quintana et al. (2017), konidiofor A. padwickii berwarna gelap, pendek atau panjang, konidium berwarna gelap dan terkadang tanwarna dengan 3-5 septa dan berbentuk kerucut (Gambar 2b) (Quintana et al., 2017).

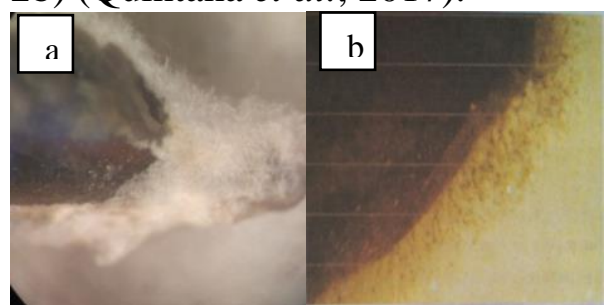

Gambar 1. Koloni Alternaria padwickii. Keterangan: a). A. padwickii perbesaran 50x; b. A. padwickii (Mathur \& Kongsdal, 2003).

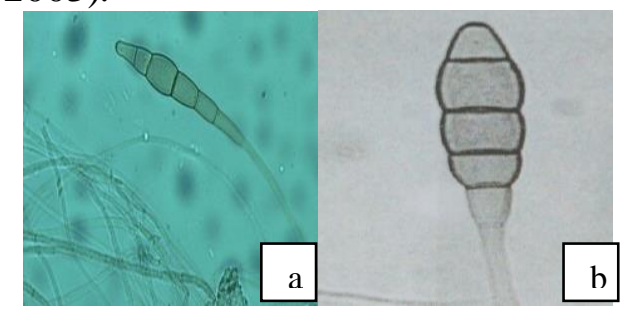

Gambar 2. Konidium Alternaria padwickii. Keterangan: a). A. padwickii perbesaran 400x; b. A. padwickii (Quintana et al., 2017).

2. Aspergillus flavus Link Aspergillus

flavus dikelompokkan sebagai jamur gudang yang mampu memproduksi mikotoksin berbahaya, dan banyak mengkontaminasi bahan pangan (Alcaide-Molina et al., 2009). Hasil pengamatan menunjukkan bahwa jamur tular-benih ini membentuk koloni berwarna hijau, berbentuk bulat dan tepi koloni rata (Gambar 3a). Morfologi jamur patogen menunjukkan bentuk seperti pohon, terdapat konidiofor, vesikel berbentuk bulat, fialid, dan konidium tanwarna, berbentuk bulat, berukuran $800 \times(15-20) \mu \mathrm{m}$, dengan vesikel berbentuk bulat sampai agak bulat. Konidiofor tanwarna, tegak dan tidak bercabang (Gambar 4a). Berdasarkan ciri-ciri morfologi yang diamati, jamur tersebut diduga $A$. flavus.

Pertumbuhan jamur pada benih yang terinfeksi A. flavus ditandai dengan koloni biasanya menyebar dan berwarna kuning kehijauan pada benih, konidiofor berbentuk panjang, konidium bulat (Gambar 3b) (Mathur \& Kongsdal, 2003). Konidiofor panjang, vesikel bulat dan didalamnya terdapat spora, fialid timbul langsung dari seluruh permukaan vesikel. Konidium bulat dan menjadi bundar lonjong (Gambar 4b) (Campbell et al., 2013).

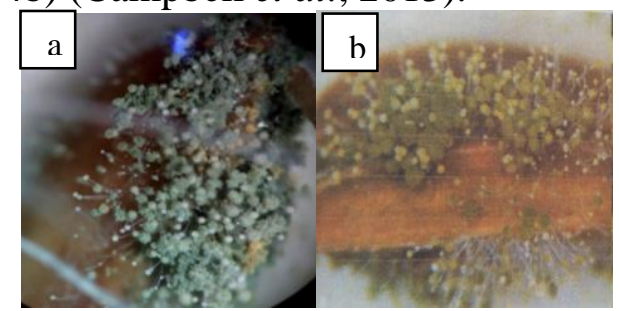

Gambar 3. Koloni Aspergillus flavus dipermukaan benih. Keterangan: a). A. flavus perbesaran 50x (Dokumentasi pribadi, 2019); b. A. flavus (Mathur \& Kongsdal, 2003).

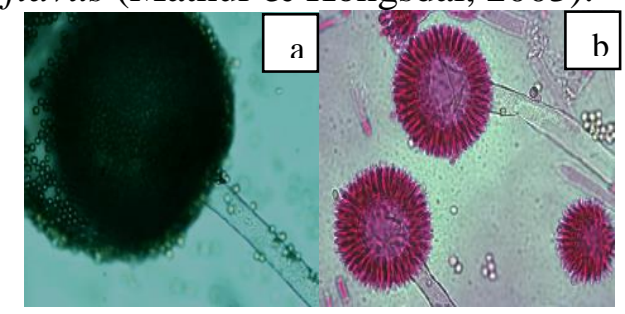

Gambar 4. Konidium Aspergillus flavus. Keterangan: a). A. flavus perbesaran 400x (Dokumentasi pribadi, 2019); b. A. flavus (Campbell et al., 2013)).

3. Aspergillus niger van Tieghem 
Aspergillus niger merupakan
spesies yang dapat membuat
pembusukan saat pascapanen
(Dijksterhuis \& Wosten, 2013). Pengamatan morfologi koloni jamur tular-benih tampak koloni berbentuk bulat, tekstur lembut, tepi koloni rata, serta berwarna hitam. Koloni tumbuh dalam waktu tiga hari dengan pertumbuhan yang menyebar (Gambar 5a). pengamatan jamur patogen di bawah mikroskop menunjukkan konidium berbentuk bulat dan berwarna hitam, konidiofor tanwarna, panjang berukuran 400$3000 \mu \mathrm{m}$, lembut, dan tidak bersekat. Konidium berwarna coklat sampai hitam, sangat kasar, berbentuk bulat, dengan diameter 4-5 $\mu \mathrm{m}$ (Gambar 6a). Berdasarkan ciri-ciri morfologi yang diamati, jamur tersebut diduga A. niger.

Koloni A. niger pada benih tumbuh perlahan, miselium basal berwarna putih sampai hitam samar. Struktur konidium, biasanya berwarna hitam atau berwarna coklat kehitaman, menutupi keseluruhan benih (Gambar 5b) (Navi et al., 1999). Jamur A. niger memiliki tekstur butiran, kepala konidium berbentuk bulat berwarna hitam, dinding konidiofor tebal, halus, dan tanwarna merupakan ciri khas jamur. Vesikel berbentuk bulat hingga semi bulat. Fialid terbentuk pada metula. Konidium berbentuk bulat hingga semibulat, berukuran 3,5 sampai 5 $\mu \mathrm{m}$, dan berwarna coklat (Gambar 6b) (Campbell et al., 2013).

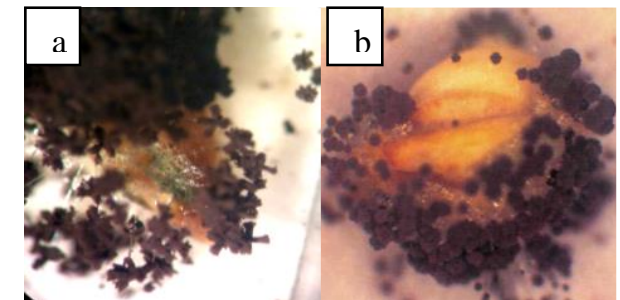

Gambar 5. Koloni Aspergillus niger di permukaan benih. Keterangan: a). $A$. niger perbesaran 50x (Dokumentasi pribadi, 2019); b. A. niger (Navi et al., 1999).

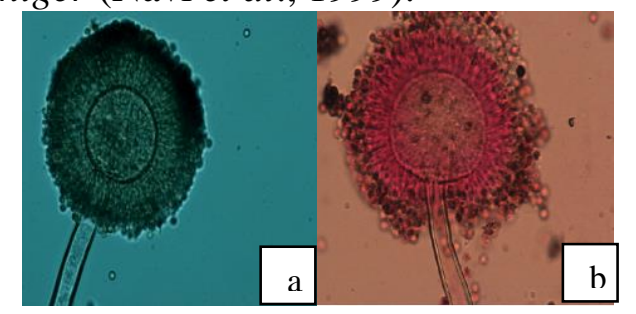

Gambar 6. Konidium Aspergillus niger. Keterangan: a). A. niger perbesaran 400x (Dokumentasi pribadi, 2019); b. A. niger (Campbell et al., 2013).

4. Curvularia lunata (Wakker) Boedjin

Curvularia lunata merupakan jamur yang menyebabkan penyakit kernel hitam (Ou, 1985). Pengamatan koloni jamur tular-benih menunjukkan koloni berwarna kelabu kehitaman, dengan permukaan halus seperti kapas, bagian tepi koloni tidak rata. Kecepatan pertumbuhan miselium dalam 5 hari pada suhu pertumbuhan $27^{\circ} \mathrm{C}$ (Gambar 7a). Pengamatan morfologi di bawah mikroskop menunjukkan konidium berbentuk melengkung, berwarna pucat hingga hitam, memiliki 3 septa, sel ketiga memiliki ukuran paling besar dan paling gelap (Gambar 8a). Berdasarkan karakter yang telah diamati, jamur tersebut diduga $C$. lunata. 
Hal ini didukung dengan pernyataan Navi et al. (1999), C. lunata memiliki karakter makroskopis berupa koloni pada benih berwarna coklat, abu-abu, atau hitam, berbulu, seperti kapas dan menyebar bebas (Gambar 7b). Ciri mikroskopis $C$. lunata memiliki konidium 3 septa. Bentuk konidium sebagian besar lengkung dan berwarna hitam, sel ketiga dari pangkalan biasanya yang paling gelap, ini merupakan ciri khas dari jamur C. lunata (Gambar 8b) (Benoit \& Mathur, 1970).

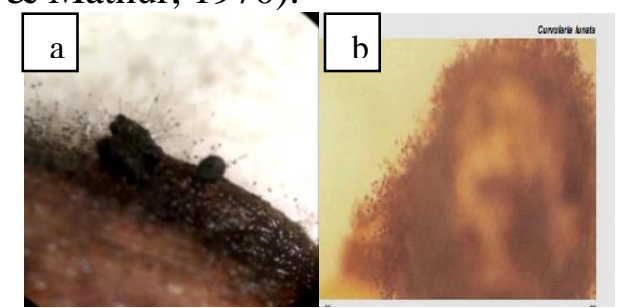

Gambar 7. Koloni Curvularia lunata di permukaan benih. Keterangan: a). C. lunata perbesaran 50x (Dokumentasi pribadi, 2019); b. C. lunata (Navi et al., 1999).

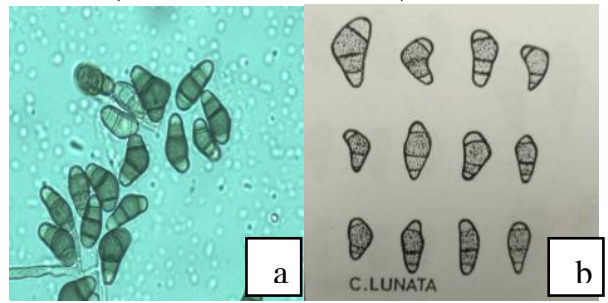

Gambar 8. Konidium Curvularia lunata. Keterangan: a). C. lunata perbesaran 400x (Dokumentasi pribadi, 2019); b. C. lunata (Benoit \& Mathur, 1970).

\section{Curvularia pallescens Boedjin}

Jamur Curvularia pallescens menunjukkan warna hitam pada bebijian, sehingga mengurangi nilai pasarnya (Mew \& Gonzalez, 2002). Pengamatan koloni jamur menunjukkan koloni berwarna hitam dengan permukaan halus seperti kapas, bagian tepi koloni tidak rata (Gambar 9a). Pengamatan morfologi jamur patogen menunjukkan konidium beberapa melengkung, memiliki 3 septa, sel ketiga memiliki ukuran paling besar, sel akhir berwarna lebih pucat. Konidiofor tanwarna (Gambar 10a). Berdasarkan karakteri yang telah diamati, jamur tersebut diduga $C$. pallescens.

Hal ini didukung dengan pernyataan Navi et al. (1999), C. pallescens memiliki karakteristik makroskopis berupa koloni pada benih berwarna coklat, abu-abu, atau hitam, tingkat pertumbuhan miselium 7,0-7,7 cm setelah empat hari (Gambar 9b). Ciri mikroskopis menunjukkan konidium berwarna coklat pucat, tidak berkelompok, biasanya lurus atau hanya sedikit melengkung dan memiliki 3-4 septa. Konidiofor berwarna kelabu atau kelabu pucat (Gambar 10b) (Salleh, et al., 1996).

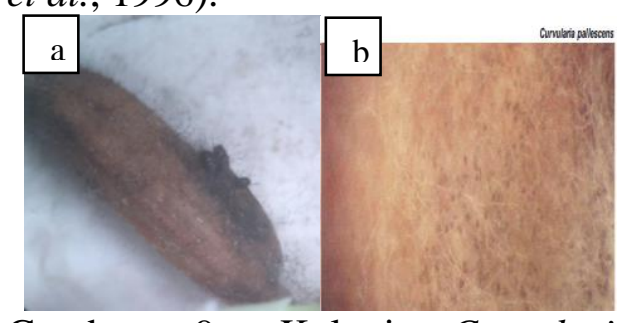

Gambar 9. Koloni Curvularia pallescens di permukaan benih. Keterangan: a). $\quad$. pallescens perbesaran 50x (Dokumentasi pribadi, 2019); b. C. pallescens (Navi et al., 1999).

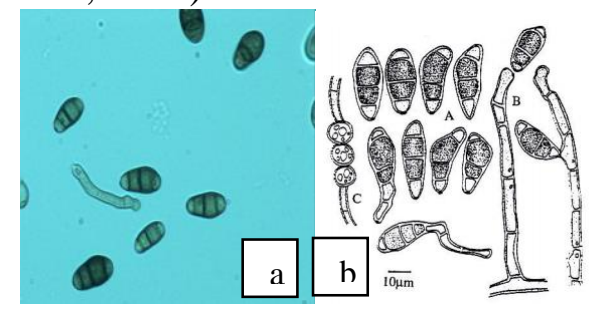


Gambar 10. Konidium Curvularia pallescens. Keterangan: a). $C$. pallescens perbesaran 400x (Dokumentasi pribadi, 2019); b. C. pallescens (Salleh et al., 1996).

6. Drechslera oryzae Breda de Haan

Drechslera oryzae merupakan jamur yang dapat menyebabkan penyakit bercak coklat pada tanaman padi (Abadi, 2003). Pengamatan koloni jamur tular-benih menunjukkan miselium berwarna putih dan berubah menjadi kelabuan dengan pertumbuhan lambat (Gambar 11a). Pengamatan morfologi di bawah mikroskop menunjukkan konidium berbentuk sedikit melengkung memiliki 9 septa, berukuran 30,4 $\times 14,1 \mu \mathrm{m}$, dan tanwarna (Gambar 12a). Berdasarkan karakteristik yang telah diamati, jamur tersebut diduga $D$. oryzae.

Drechslera oryzae memiliki miselium berwarna kelabuan hingga kelabu kehijauan. Miselium tumbuh dengan penyebaran lambat (Gambar 11b). Ciri mikroskopis konidiofor tidak berkelompok, lurus atau terkadang membungkuk, tanwarna dan membawa konidium di ujung dan samping. Konidium berwarna coklat tua, berbentuk melengkung (sedikit bengkok di satu sisi), dan berukuran (29-33) $\times(13,5-14,8) \mu \mathrm{m}$. Konidium memiliki 7-10 septa, konidium terbesar memiliki 13 septa (Gambar 12b) (Mew \& Gonzalez, 2002).

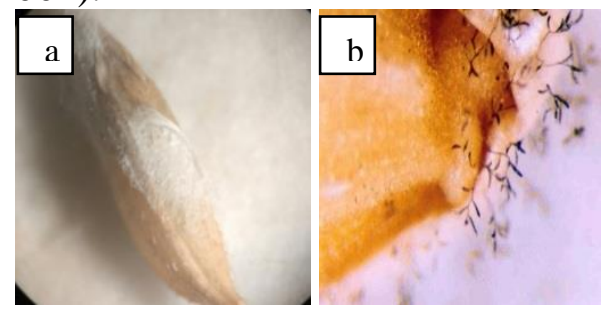

Gambar 11. Koloni Drechslera oryzae di permukaan benih. Keterangan: a). D. oryzae perbesaran 50x (Dokumentasi pribadi, 2019); b. D. oryzae (Gonzales et al., 2014).

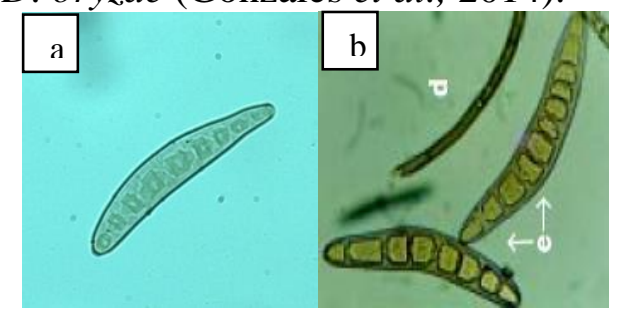

Gambar 12. Konidium Drechslera oryzae. Keterangan: a). D. oryzae perbesaran 400x (Dokumentasi pribadi, 2019); b. D. oryzae (Mew \& Gonzalez, 2002).

7. Fusarium semitectum Berk. \& Rav. [W\&R, G,B,J]

$F$. semitectum dilaporkan dapat menyebabkan layu dan rebah semai pada bibit padi (Agarwal et al., 1989). Pengamatan koloni jamur tular-benih, pada seluruh permukaan benih terdapat miselium berwarna putih hingga oranye seiring pertumbuhan dan menimbulkan gejala infeksi berwarna coklat tua pada benih (Gambar 13a). Pengamatan morfologi jamur patogen menunjukkan konidium lurus atau sedikit melengkung, tanwarna dan memiliki 7 septa. Bentuk apikal konidium meruncing atau melengkung secara mikroskopis hifa tanwarna dan bersekat (Gambar 14a). Berdasarkan karakter yang telah diamati, jamur tersebut diduga F. semitectum.

Ciri makroskopis $F$. semitectum memiliki koloni pada benih berwarna putih dan berubah menjadi merah muda atau oranye. Permukaan bawah koloni berwarna coklat (Navi et al., 1999) (Gambar $13 b)$. Ciri mikroskopis $F$. semitectum 
terdapat konidiofor yang terbentuk di miselium memiliki struktur percabangan yang longgar. Konidium tanwarna memiliki 3-7 septa. Bentuk apikal konidium berlekuk dengan sel basal berbentuk lurus (Gambar 14b) (Booth, 1971).

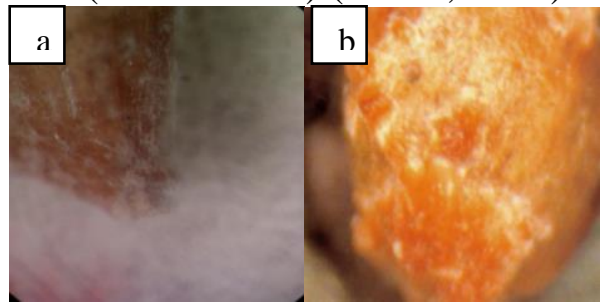

Gambar 13. Koloni Fusarium semitectum di permukaan benih. Keterangan: a). F. semitectum perbesaran 50x (Dokumentasi pribadi, 2019); b. F. semitectum (Navi et al., 1999).

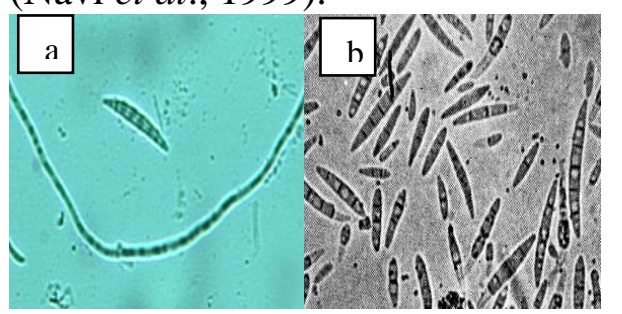

Gambar 14. Makrokonidium Fusarium semitectum. Keterangan: a). F. semitectum perbesaran $400 x$ (Dokumentasi pribadi, 2019); b. F. semitectum (Booth, 1971).

8. Rhizoctonia solani J. G. Kuhn.

Jamur $R$. solani menyebabkan penyakit hawar pelepah pada tanaman padi (Nuryanto, 2017). Pengamatan morfologi jamur tularbenih, memiliki miselium berwarna hitam keputihan, seperti benang, pada benih terdapat noda hitam (Gambar 15a). Pengamatan morfologi di bawah mikroskop menunjukkan percabangan hifa membentuk $90^{\circ}$ dan tidak berwarna, hifanya panjang dan bercabang, pada titik percabangannya terdapat lekukan, dan bersekat (Gambar 16a).
Berdasarkan karakteristik yang telah diamati, jamur tersebut diduga $R$. solani.

Ciri makroskopis dapat dilihat jamur menghasilkan miselium tebal, coklat hingga coklat tua yang menyebar secara memancar dari benih yang terinfeksi pada kertas saring dan bahkan dapat menutupi seluruh cawan Petri seperti yang terlihat pada gambar 15b (Mathur \& Kongsdal, 2003). Ciri mikroskopis menunjukkan Hifa $R$. solani memiliki percabangan pada sudut $90^{\circ}$ yang merupakan ciri khas jamur (Gambar 16b), pada titik a abangannya terdapat lekukan, ebar hifa 6-10 $\mu \mathrm{m}$, tanwarna, bersekat (Sumartini, 2011).

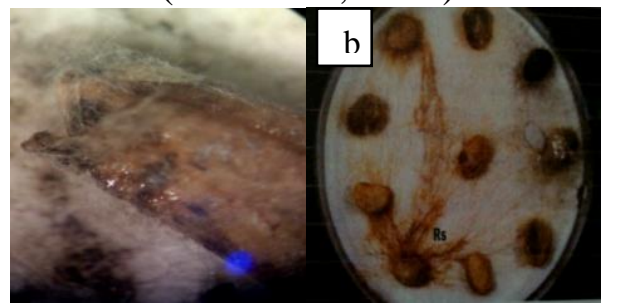

Gambar 15. Koloni Rhizoctonia solani di permukaan benih. Keterangan: a). $R$. solani perbesaran 50x (Dokumentasi pribadi, 2019); b. $R$. solani (Mathur \& Kongsdal, 2003).

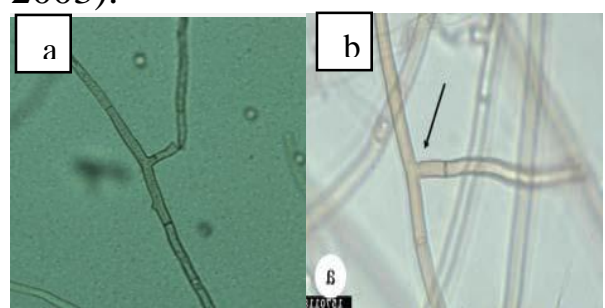

Gambar 16. Hifa Rhizoctonia solani. Keterangan: a). R. solani perbesaran 400x (Dokumentasi pribadi, 2019); b. $R$. solani (Sumartini, 2011).

9. Rhizopus oryzae Went \& Prins. Geerl.

Rhizopus merupakan jamur yang menyebabkan penyakit pada 
malai atau gabah. Gabah yang terserang terdapat bercak coklat sampai kehitaman dan gabah menjadi hampa (Semangun, 2008). Pengamatan morfologi jamur tularbenih, memiliki koloni berwarna putih menutupi seluruh benih dan meluas ke kertas blotter, sifat penyebaran jamur cepat. Koloni berwarna putih dan menjadi abu-abu dengan bertambahnya usia biakan (Gambar 17a). Pengamatan morfologi di bawah mikroskop terdapat kolumella, sporangium, dan sporangiofor. Spora berwarna hitam dan bentuk spora menyerupai bulat sampai oval. Sporangiofor bertangkai tumbuh keatas mengandung sporangium. Sporangium berwarna hitam dan columella berbentuk bulat (Gambar 18a). Berdasarkan karakteristik yang telah diamati, jamur tersebut diduga $R$. oryzae.

$R$. oryzae memiliki koloni berwarna putih dan menjadi kebuan dengan bertambahnya usia biakan (Gambar 17b). Ciri mikroskopis $R$. oryzae memiliki sporangiofor yang tegak, bercabang berwarna kekuningan hingga coklat tua, rhizoid terhubung langsung ke sporangiofor, yang mengandung sporangium. Sporangium berbentuk bulat berwarna coklat tua kehitaman, columella berbentuk bulat (Gambar 18b) (Watanabe, 2018).

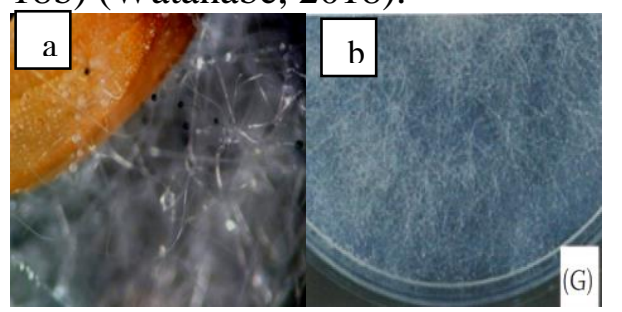

Gambar 17. Koloni Rhizopus oryzae.

Keterangan: a). $R$. oryzae di permukaan benih, perbesaran 50x
(Dokumentasi pribadi, 2019); b. $R$. oryzae (Watanabe, 2018).

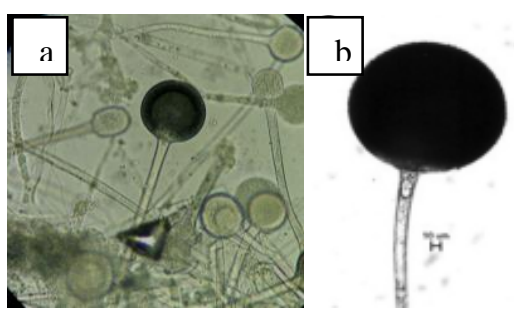

Gambar 18. Kolumela Rhizopus oryzae. Keterangan: a). $R$. oryzae perbesaran 400x (Dokumentasi pribadi, 2019); b. R. oryzae (Kwon et al., 2010).

10. Tilletia barclayana Bref.

Kernel smut adalah penyakit jamur pada padi yang disebabkan oleh Tilletia barclayana (Cheraghian, 2019). Penyakit ini terlihat pada saat panen. Bebijian yang terinfeksi dapat hancur seluruhnya atau sebagian (Elshafey, 2018).

Pengamatan morfologi jamur tular-benih, terdapat spora berwarna hitam berbentuk bulat. Benih berubah warna menjadi kehitaman dan hampa (Gambar 19a). Pengamatan morfologi di bawah mikroskop terdapat konidium bulat, teliospore berduri dan berwarna hitam, berukuran 18-32,9 $\mu \mathrm{m}$ (Gambar 20a). Berdasarkan karakteristik yang telah diamati, jamur tersebut diduga $T$. barclayana.

Hal ini didukung dengan pernyataan (NAPPO, 2014), makroskopis $T$. barclayana ditandai dengan penggantian endosperma kernel dengan massa spora hitam. Benih menjadi hampa dan terdapat pustula hitam (Gambar 19b). Karakteristik mikroskopis $T$. barclayana memiliki konidium berwarna kemerahan atau coklat. 
Berbentuk bulat. Teliospore berduri dan panjang (Gambar 20b).

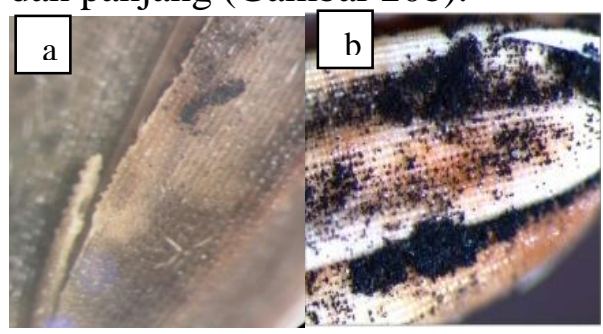

Gambar 19. Koloni Tilletia barclayana di permukaan benih. Keterangan: a). T. barclayana perbesaran 50x (Dokumentasi pribadi, 2019); b. T. barclayana (NAPPO, 2014).

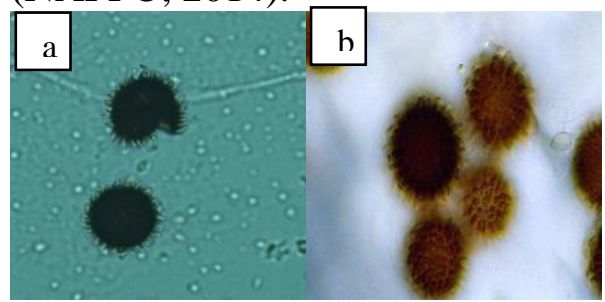

Gambar 20. Konidium Tilletia barclayana. Keterangan: a). $T$. barclayana perbesaran 400x (Dokumentasi pribadi, 2019); b. T. barclayana (NAPPO, 2014).

\section{Daya Kecambah Benih}

Tabel 2. Daya kecambah benih

\begin{tabular}{ll}
\hline Perlakuan & $\begin{array}{c}\text { Daya Kecambah } \\
\text { Benih }(\%)\end{array}$ \\
\hline V1 & $80,25 \mathrm{~b}$ \\
V2 & $76,5 \mathrm{~b}$ \\
V3 & $85,75 \mathrm{c}$ \\
V4 & $81,75 \mathrm{bc}$ \\
V5 & $70 \quad \mathrm{a}$ \\
\hline
\end{tabular}

Keterangan: Angka diikuti huruf yang berbeda pada kolom sama menunjukkan berbeda nyata pada uji BNJ dengan taraf kesalahan 5\%. $\mathrm{V} 1=$ varietas Inpago Unsoed 1, V2= varietas Inpago Unsoed Parimas, $\mathrm{V} 3=$ varietas IR64, V4= varietas
Ciherang, dan V5= varietas Situ Bagendit.

Berdasarkan hasil penelitian pada Tabel 2, masing-masing varietas padi mempunyai persentase perkecambahan yang berbeda. Perbedaan daya kecambah ini diduga disebabkan oleh faktor genetika tanaman dan faktor luar atau lingkungan. Hal ini sesuai dengan pendapat Vidotto \& Ferrero (2000) dan Miransari \& Smith (2014), bahwa kemampuan benih untuk berkecambah dipengaruhi oleh tindakan budidaya benih, kondisi lingkungan, dan status dormasi benih untuk mengelola perkecambahan benih. Daya kecambah benih berturut-turut pada varietas IR64, Ciherang, Inpago Unsoed 1, Inpago Unsoed Parimas, dan Situ Bagendit sebesar 85,$75 ; 81,75 ; 80,25 ; 76,5$; dan $70 \%$.

Hal ini sesuai dengan pernyataan Amteme dan Tefa (2018), bahwa sertifikasi untuk benih padi mensyaratkan nilai standar daya berkecambah yang tergolong tinggi yaitu minimum $80 \%$. Halindra et al. (2017) menambahkan, sekitar 58,3\% dari lahan Kalimantan Barat ditanami varietas unggul seperti IR 64, padi gogo, dan Ciherang yang memiliki keunggulan yaitu mutu benih berkualitas tinggi dengan daya tumbuh minimum $80 \%$, malai yang panjang dan lebar, rasa nasi pada umumnya pulen, dan beberapa di antaranya mengeluarkan aroma.

Pengamatan benih padi yang tidak mampu berkecambah, umumnya menunjukkan gejala berupa diselimutinya permukaan benih oleh jamur patogen tular-benih 
berupa miselium (Gambar 21a). Pada benih yang berkecambah dan terserang jamur menunjukkan gejala benih menjadi kehitaman dan diselimuti oleh miselium (Gambar 21b).

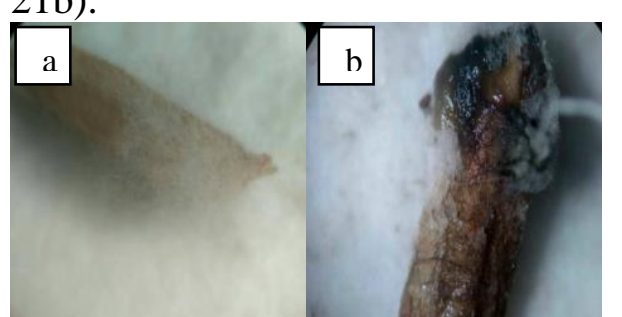

Gambar 21. Gejala penyakit pada perkecambahan benih: a). Permukaan benih diselimuti oleh miselium sehingga tidak berkecambah; $b$. Benih berkecambah dan terdapat bercak (Dokumentasi pribadi, 2019).

\section{Keberadaan jamur pada benih dapat menimbulkan terjadinya penyakit mulai fase benih, persemaian, tanaman muda dan dewasa. Deteksi jamur pada benih dapat digunakan untuk mendapatkan tindakan apa yang paling tepat untuk penanganan jamur tular-benih, supaya benih dapat tumbuh dan menghasilkan tanaman yang sehat. Gejala infeksi jamur memiliki dampak yang berbeda pada benih (Ramdan dan Kalsum, 2017).}

\section{SIMPULAN}

Simpulan hasil penelitian ini adalah: 1) Jenis jamur patogen tular-benih yang dijumpai pada benih padi, yaitu Alternaria padwickii Ganguly, Aspergillus flavus Link, Aspergillus niger van Tieghem, Curvularia lunata (Wakker) Boedjin, Curvularia pallescens Boedjin, Drechslera oryzae Breda de Haan, Fusarium semitectum Berk. \& Rav. [W\&R, G,B,J], Rhizoctonia solani J. G.
Kuhn, Rhizopus oryzae Went \& Prins. Geerl., dan Tilletia barclayana Bref. 2) Hasil uji daya kecambah menunjukkan bahwa masing-masing varietas benih padi memilki persentase daya kecambah benih yang berbeda. Persentase daya kecambah benih yang tertinggi secara berturut-turut terdapat pada varietas IR64, Ciherang, Inpago Unsoed 1, Inpago Unsoed Parimas, dan Situ Bagendit sebesar 85,75; 81,$75 ; 80,25 ; 76,50$; dan 70,00\%.

\section{DAFTAR PUSTAKA}

Abadi, A. (2003). Ilmu Penyakit Tumbuhan. Bayu Media.

Agarwal, P. C., Mortensen, C. N., \& Mathur, S. B. (1989). Seedborne Diseases and Seed Health Testing of Rice. Commonwealth Mycological Institute. UK. 106 pp.

Alcaide-Molina, M., Ruiz-Jiménez, J., Mata-Granados, J. M., \& Luque de Castro, M. D. (2009). High through-put aflatoxin determination in plant material by automated solidphase extraction on-line coupled to laser-induced fluorescence screening and determination by liquid chromatography-triple quadrupole mass spectrometry. J Chromatogr A, 1216(7), 1115-1125.

Amteme, K., \& Tefa, A. (2018). Identifikasi Cendawan Patogen pada Beberapa Varietas Benih Padi Sawah Berdasarkan Model Penyimpanan. Savana Cendana, 3(01), 4-7. https://doi.org/10.32938/sc.v3i0 1.150

Benoit, M. A., \& Mathur, S. B. 
(1970). Identifiacation of Curvularia on rice seed. Proc. Int. Seed Test. Ass., 35(1), 99119.

Booth, C. (1971). The Genus Fusarium. Commonwealth Mycological Institute. England. $128 \mathrm{pp}$.

Campbell, C. K., Jhonson, E. M., \& Warnock, D. (2013). Identification of Pathogenic Fungi, (Second Edi). WileyBlackwell. Hoboken. 337 pp.

Cheraghian, A. (2019). A Guide for Diagnosis and Direction of Quarantine Pests Black Smut of Rice Tilletia barclayana (Bref.) Sacc. \& P. Syd. Basidiomycota: Tilletiaceae. Bureau of Plant Pest Surveillance and Pest Risk Analysis.

Cram, M. M., \& Fraedrich, S. W. (2010). Seed diseases and seedborne pathogens of North America. Tree Planters' Notes, 53(2), 35-44.

Desjardins, A. E., Manandhar, H. K., Plattner, R. D., Manandhar, G. G., Poling, S. M., \& Maragos, C. M. (2000). Fusarium species from nepalese rice and production of mycotoxins and gibberellic acid by selected species. Applied and Environmental Microbiology, 66(3), 1020-1025. https://doi.org/10.1128/AEM.66 .3.1020-1025.2000

Dijksterhuis, J., \& Wosten, H. (2013). Development of Aspergillus niger. CBS-KNAW. Netherlands. 96 pp.

Ellis, M. B. (1997). Dematiaceous Hypomycetes. Commonwealth Mycological Institute. England. $604 \mathrm{pp}$.
Elshafey, R. A. S. (2018). Biology of rice kernel smut disease causal organism Tilletia barclayana and its molecular identification. Journal of Phytopathology and Pest Management, 5(2), 108128.

Gonzales, P., Gonzales, E., Huelma, C., Almodiel, M., \& Dumlao, J. (2014). Fungi-rice. IRRI, Seed Health Unit, Los Banos, Philippines.

Halindra, Y. M., Rusmiyanto, E., \& Linda, R. (2017). Perkecambahan Benih Padi (Oryza sativa L.) Lokal Asal Kalimantan Barat Berdasarkan Tingkat Salinitas. Jurnal Protobiont, 6(3), 295-302.

Hausufa, A., \& Rusae, A. (2018). Cendawan Patogen pada Beberapa Varietas Jagung di Kabupaten Timor Tengah Utara. Savana Cendana, 3(02), 21-23. https://doi.org/10.32938/sc.v3i0 2.153

Ibeabuchi, C., \& Olawuni, I. (2011). Isolation and identification of spoilage fungi associated with rice (Oryzae sativa), millet (Pennisetum americanum) and soybean. International Journal of Agriculture and Rural Development, 14(2), 614-616.

ISTA. (1996). International Rules for Seed Testing, Rules 1996. Seed Science and Technology 24 (supplement). Zurich, Switzerland.

Kwon, J.-H., Kim, J., Lee, Y.-H., \& Shim, H.-S. (2010). Soft Rot on Cucumis melo var. makuwa Caused by Rhizopus oryzae . Mycobiology, 38(4), 336. https://doi.org/10.4489/myco.20 10.38.4.336 
Mathur, S. B., \& Kongsdal, O. (2003). Common Laboratory Seed Health Testing Methods for Detecting Fungi. Bassedorf $(\mathrm{CH}): \quad$ International Seed Testing Assosiation. 275 pp.

Mew, T. W., \& Gonzalez, P. (2002). A Handbook of Rice Seed-borne Fungi. IRRI. Los Banos. 83 pp.

Miransari, M., \& Smith, D. L. (2014). Plant hormones and seed germination. Environmental and Experimental Botany, 99, $110=121$. https://doi.org/0.1016/j.envexpb ot.2013.11.005

NAPPO. (2014). NAPPO Standards for Phytosanitary Measures ( RSPM ) A Harmonized Procedure for Morphologically Distinguishing Teliospores of Karnal Bunt from Ryegrass Bunt, Rice Smut and Similar Smuts. The Secretariat of the North American Plant Protection Organization. America $12 \mathrm{p}$.

Navi, S. S., Singh, S. D., Lenne, J. M., Kirk, P. M., \& Brayford, D. (1999). New grain mold fungi of sorghum in India. Journal of Mycology and Plant Pathology, 27, 104-105.

Ngittu, Y. S., Mantiri, F. R., Tallei, T. E., Febby, D., \& Kandou, E. F. (2014). Identifikasi genus jamur Fusarium yang menginfeksi eceng gondok (Eichhornia crassipes) di Danau Tondano. Pharmacon Jurnal Ilmiah Farmasi, 3(3), 23022493.

Ningsih, R., Mukarlina, \& Linda, R. (2012). Isolasi dan identifikasi jamur dari organ bergejala sakit pada tanaman jeruk siam (Citrus nobilis var. microcarpa). Probiont, 1(1), 1-7.

Nuryanto, B. (2017). Penyakit Hawar Pelepah (Rhizoctonia solani) pada Padi dan Taktik Pengelolaannya. Jurnal Perlindungan Tanaman Indonesia, 21(2), 63. https://doi.org/10.22146/jpti.224 94

Ou, S. H. (1985). Rice Diseases. Commonwealth Mycological Institute. Kew Surrey. England. $411 \mathrm{pp}$.

Pratiwi, N. W., Juliantari, E., \& Napsiyah, L. K. (2016). Identifikasi Jamur Penyebab Penyakit Pascapanen pada Beberapa Komoditas Bahan Pangan. Jurnal Riau Biologia, 1(14), 86-94.

Quintana, L., Gutierrez, S., Maidana, M., Arriola, M., \& Ortiz, A. (2017). Morphological characterization of Alternaria padwickii in rice leaves (Oryza sativa L.) and its prevalence in the departments of itapua, misiones and caazapa. IJAR, 5(15), 1109-1112.

Ramdan, E. P., \& Kalsum, U. (2017). Inventarisasi cendawan terbawa benih padi, kedelai, dan cabai. Jurnal Pertanian Presisi, 1(1), 48-58.

Salleh, B., Safinat, A., Julia, L., \& Teo, C. H. (1996). Brow spot caused by Curvularia spp. a new disease of asparagus. Biotropia, 90(9), 26-37.

Saylendra, A. (2010). Identifikasi cendawan terbawa benih padi dari Kecamatan Ciruas Kabupaten Serang Banten. Jurnal Agroekotek, 2(2), 24-27. 
Semangun, H. (2008). PenyakitPenyakit Tanaman Pangan di Indonesia. Gadjah Mada University Press. Yogyakarta. 449 hal.

Sucipto, I., Munif, A., Suryadi, Y., \& Tondok, E. T. (2015). Eksplorasi Cendawan Endofit Asal Padi Sawah sebagai Agens Pengendali Penyakit Blas pada Padi Sawah. Jurnal Fitopatologi Indonesia, 11(6), 211-218. https://doi.org/10.14692/jfi.11.6 .211

Sumartini. (2011). Penyakit tular tanah (Sclerotium rolfsii dan Rhizoctonia solani) pada tanaman kacang-kacangan dan umbi-umbian serta cara pengendaliannya. Jurnal
Litbang Pertanian, 31(1), 2734.

Uma, V., \& Wesely, E. (2013). Seed borne fungi of rice from South Tamil Nadu. J. Acad. Indus. Res, 1(March), 612-614.

Vidotto, F., \& Ferrero, A. (2000). Germination behaviour of red rice (Oryza sativa L.) seeds in field and laboratory conditions. Agronomie, EDP Sciences, 20(4), 375-382. https://doi.org/10.1051/agro:200 0134.

Watanabe, T. (2018). Pictorial Atlas of Soilbone Fungal Plant Pathogens and Diseases. CRC Press. Florida. 298 pp. 